\title{
Agronomic and nutritional characteristics of Massai grass subjected to deferred grazing and nitrogen fertilization
}

\section{Características agronômicas e nutritivas de pastos de capim-Massai com pasto diferido e adubação nitrogenada ${ }^{1}$}

\author{
Clésio dos Santos Costa ${ }^{2 *}$; Rosane Cláudia Rodrigues ${ }^{3}$; Ricardo Alves de Araújo ${ }^{2}$; \\ Magno José Duarte Cândido ${ }^{4}$; Francisco Naysson de Sousa Santos ${ }^{5}$; \\ Marcônio Martins Rodrigues ${ }^{6}$; Francivaldo Oliveira Costa ${ }^{7}$; \\ Ivone Rodrigues da Silva ${ }^{8}$; Arnaud Azevêdo Alves ${ }^{9}$; Noilson Monteles de Lima ${ }^{10}$
}

\begin{abstract}
This study aimed to evaluate the agronomic characteristics and nutritional value of Massai grass (Megathyrsus maximus 'Massai') pastures fertilized with different nitrogen levels and subjected to deferred grazing. A completely randomized experimental design (CRD) was adopted, with including five nitrogen levels (zero, 100, 200,300, and $400 \mathrm{~kg} \mathrm{ha}^{-1}$ ), and five replications (plots). The degradability trial used a CRD including a $6 \times 5$ factorial arrangement, consisting of six rumen-incubation times $(6$, $24,48,60,84$, and $96 \mathrm{~h}$ ) and five levels of nitrogen in different plots. One fistulated sheep, with a live weight of $60 \mathrm{~kg}$, was used in the experiment. Total herbage biomass, dead herbage biomass, and height showed a quadratic response to nitrogen fertilization levels of 100 to $200 \mathrm{~kg} \mathrm{ha}^{-1}$ resulted in greater tillering. Protein and dry matter content increased linearly with nitrogen fertilization level, leading to increase in fibrous components. The increase in NDF and ADF contents might be a consequence of the reduction in NCE, and the high flowering rate of the grass, owing likely to the reduction in metabolism of the grass in an attempt to extend its lifetime. Nitrogen levels of $300 \mathrm{~kg} \mathrm{ha}^{-1}$ or higher affected the productive characteristics positively, whereas the chemical characteristics were negatively affected. Key words: Deferred period. Degradability of dry matter. Megathyrsus. Nitrogen fertilization.
\end{abstract}

\section{Resumo}

Objetivou-se avaliar as características agronômicas e valor nutritivo do capim-Massai (Megathyrsus maximus 'Massai') submetido a diferimento e doses crescentes de nitrogênio. $O$ delineamento experimental adotado foi o inteiramente casualizado (DIC) com cinco doses de nitrogênio (zero,

1 Trabalho de conclusão de curso do primeiro autor.

2 Discentes do Programa de Doutorado Integrado em Zootecnia-PDIZ, UFC, Chapadinha, MA, Brasil. E-mail: clesiosantzoo@, gmail.com; ricardo_zoo@hotmail.com

${ }^{3}$ Prof $^{a}$ Dr $^{\mathrm{a}}$, Curso de Zootecnia, UFMA, Chapadinha, MA, Brasil. E-mail: rosanerodrig@gmail.com

${ }^{4}$ Prof. Dr., Departamento de Zootecnia, UFC, Fortaleza, CE, Brasil. E-mail: magno@ufc.br

${ }^{5}$ Discente de Mestrado do Programa de Pós-Graduação em Zootecnia, Universidade Federal do Ceará, UFC, Fortaleza, CE, Brasil. E-mail: nayssonzootecnista@gmail.com

${ }^{6}$ Bolsista DCR FAPEMA/CNPq, UFMA, Chapadinha, MA, Brasil. E-mail: marnunes07@yahoo.com.br

7 Zootecnista, M.e em Ciência Animal. E-mail: francivaldo.oliveira@hotmail.com

8 Discente de Doutorado do Programa de Pós-Graduação em Ciência Animal, UFPI, Teresina, PI, Brasil. E-mail: ivonerodrigues10@ hotmail.com

${ }^{9}$ Prof. Dr., Departamento de Zootecnia, Universidade Federal do Piauí, Teresina, PI, Brasil. E-mail: arnaud@ufpi.edu.br

${ }^{10}$ Zootecnista. E-mail: noilson83@hotmail.com

* Author for correspondence 
100; 200; 300 e $400 \mathrm{~kg}$ de $\mathrm{N} \mathrm{ha}^{-1}$ ) com cinco repetições (parcelas). O ensaio de degradabilidade foi estruturado em DIC, com arranjo fatorial $6 \times 5$, seis tempos de incubação no rúmen $(6,24,48,60,84$ e 96 h) e cinco doses de $\mathrm{N}$ em parcelas diferidas. Utilizou-se um ovino fistulado com peso vivo de $60 \mathrm{~kg}$. A biomassa de forragem total, morta e a altura respondeu à adubação nitrogenada de forma quadrática. A adubação nitrogenada nas doses 100 a $200 \mathrm{~kg} \mathrm{de} \mathrm{N} \mathrm{ha}^{-1}$ proporcionou maior perfilhamento. A adubação nitrogenada proporcionou resposta linear sobre os teores de proteína e matéria seca em consequência também aumentou os constituintes fibrosos. O amento dos teores de FDN e FDA pode ser uma consequência da redução da ECN e da taxa de florescimento da gramínea, devido provavelmente à redução no metabolismo na tentativa de prolongar sua vida útil. A partir da dose de $300 \mathrm{~kg}$ de $\mathrm{N} \mathrm{ha}{ }^{-1}$ resultou em redução da degradação da matéria seca do capim-Massai. As doses de $\mathrm{N}$ influenciaram positivamente as características produtivas e negativamente as características químicas.

Palavras-chave: Adubação nitrogenada. Degradabilidade da MS. Megathyrsus. Período de diferimento.

\section{Introduction}

Herbage is the main source of feed for ruminants, as it is a low-cost, high-quality product. However, one of the main obstacles in pasturebased production in Brazil is the marked rainfall seasonality in many regions, which leads to a lack of quality feed, and negatively affects production. In this scenario, alternatives to improve the availability of quality feedstuff in the period of scarcity need to be explored.

Preserving the forage harvested in the period of higher production for use during scarcity has been a successful alternative. Besides the predominant methods of hay- and silage-making, pasture deferment is another method of storing the surplus forage. Pasture deferment, also known as pasture "closure," is a management strategy that excludes certain areas of the pasture from grazing later use, with the aim of minimizing the effects of forage production seasonality (SANTOS et al., 2009a).

However, this technique requires care during management, since several factors can lead to loss of nutritional value in forage crops. Owing to the negative correlation with the age of the plants, some loss in their nutritional value is inevitable. It is important to choose a species that adapts to the conditions of the dryland region in order to successfully manage the deferred pastures (EUCLIDES et al., 2007). In addition, the species must produce thin, high leaf stalk/stem, and loss of nutritional value over time should be slow
(SANTOS et al., 2010). The use of nitrogen fertilizer at the beginning of the deferral period may be of fundamental importance for increasing forage production, ensuring that the plants retain vigor, and ensuring that their nutritional values do not reduce drastically during long deferral periods.

Nitrogen is considered one of the most important nutrients for the management and persistence of a pasture (FRANÇA et al., 2007). Nitrogen fertilization increases growth rate and tissue renewal of plants, thereby increasing the carrying capacity of the pasture (SANTOS et al., 2009a).

However, Santos et al. (2010) suggested that high levels of nitrogen should not be applied at the beginning of the deferral period, owing to the fact that an increase in plant growth rate and physiological maturity reduces nutritional value. In light of this question, the aim of the present study was to evaluate the effect of nitrogen on deferred pastures of Massai grass in order to establish a fertilization regime for ensuring good production and nutritional characteristics.

\section{Material and Methods}

The experiment was conducted in the Forage Crops Unit of the Center for Agricultural and Environmental Sciences at the Federal University of Maranhão, Chapadinha-MA, Brazil (034' $33^{\prime \prime}$ S, 4321'21” W), from April 19 to August 20, 2014. Precipitation and temperature conditions during 
the experimental period have been summarized in Figure 1.

Soil from the experimental area was a Yellow Latisol, according to the Embrapa (1999) classification, with the following chemical characteristics: $\mathrm{pH}$ in $\mathrm{CaCl}_{2}=4.8, \mathrm{OM}=17 \mathrm{~g} \mathrm{dm}^{-3}$, $\mathrm{Pb}=7, \mathrm{~S}=8 \mathrm{mg} \mathrm{dm}^{3-1} ; \mathrm{K}=2.5, \mathrm{Ca}=4, \mathrm{Mg}=2, \mathrm{H}$ $+\mathrm{Al}=21, \mathrm{Al}=1, \mathrm{CEC}=29$, sum of bases $=8 \mathrm{mmol}$ $\mathrm{dm}^{-3} ; \mathrm{BS}=29 \%, \mathrm{Al}$ saturation $=10 \%, \mathrm{~B}=1.31, \mathrm{Cu}$ $=0.1, \mathrm{Fe}=31, \mathrm{Mn}=0.3$, and $\mathrm{Zn}=0.4 \mathrm{mg} \mathrm{dm}^{-1}$. Liming was carried out using dolomitic limestone with the aim of increasing the saturation by base to
$60 \%$. Massai-grass plots were leveled to a height of $20 \mathrm{~cm}$ and closed for 121 days. Based on the soil analysis report (CANTARUTTI et al., 1999), the plot was fertilized with $90 \mathrm{~kg} \mathrm{P}_{2} \mathrm{O}_{5}$ per hectare and 60 $\mathrm{kg} \mathrm{K}_{2} \mathrm{O}$ per hectare using single superphosphate and potassium chloride, respectively. The phosphorus source was applied only once, when the experiment was started, whereas the potassium source was split into three applications of $20 \mathrm{~kg} \mathrm{~K}_{2} \mathrm{O}$ ha $^{-1}$ together with the nitrogen levels. They were applied early in the morning, when milder temperatures minimized the loss of nitrogen due to volatilization.

Figure 1. Average monthly temperature and precipitation during the experimental period.

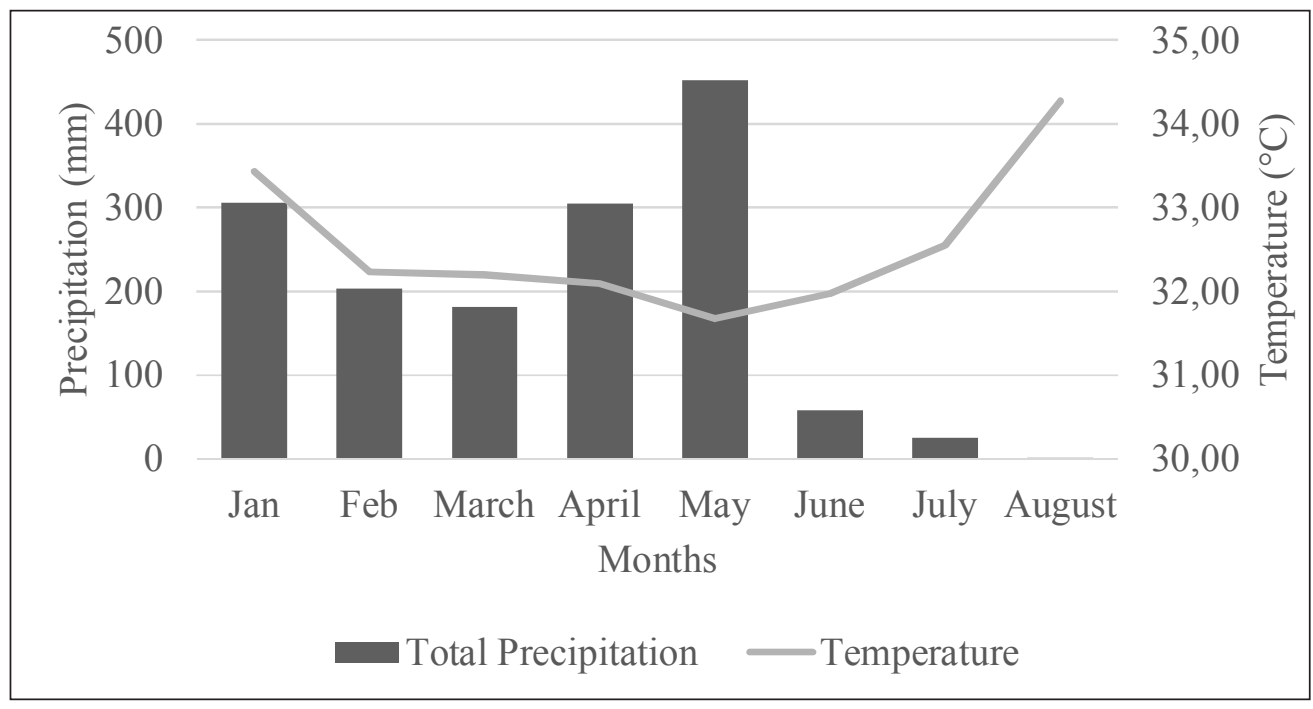

A completely randomized design (CRD) with five nitrogen levels $(0,100,200,300$, and $400 \mathrm{~kg}$ $\mathrm{ha}^{-1}$ ) and five replications (plots) was used. Nitrogen was applied in the form of urea, split into three applications, the first being after the plot-leveling cut, and the others at every 30 days, to minimize the effect of loss by volatilization.

To evaluate productive characteristics, a square with an area of $0.25 \mathrm{~m}^{2}$, made by bending a PVC tube, was thrown over the plot five times, and the forage within it was cut $20 \mathrm{~cm}$ above the ground surface, according to the recommendations of Barbosa et al. (2010). The live and dead tillers were counted. The harvested forage was separated into live and dead parts, and dried in a forced-air oven at $55^{\circ} \mathrm{C}$ for $72 \mathrm{~h}$. After drying, the material was weighed and the total herbage biomass (THB), dead herbage biomass (DHB), and green herbage biomass (i.e., green leaves and stems; GHB) were quantified.

Pre-dried forage samples were used for determination of the dry matter (DM) and crude protein (CP), following the protocol of AOAC (2012), neutral detergent fiber (NDF), according to the methodology of Van Soest et al. (1991), and acid detergent fiber (ADF) and lignin, according to the methodology of Van Soest (1963). 
Dry matter degradability was estimated in situ, using a crossbred sheep weighing $60 \mathrm{~kg}$, following the procedure suggested by Tomich and Sampaio (2004). The sheep was fed with chopped elephant grass. Samples of the Massai-grass pasture were ground to $2 \mathrm{~mm}$ and inserted in $12 \times 8 \mathrm{~cm}$ nylon bags with $50-\mu \mathrm{m}$ pore size (NOCEK, 1988). A CRD with a $6 \times 5$ factorial arrangement (six incubation times and five deferred plots) was adopted. Incubation times were 6, 24, 48, 60, 84, and $96 \mathrm{~h}$.

In situ dry matter (DM) degradation parameters ( $a, b$, and c) were estimated by the model of Ørskov e Mcdonald. (1979), modified by Sampaio (1995), as follows: $D P=A-B \cdot e^{-c \cdot t}$; in which $A=$ maximum degradation potential, $B=$ potentially degradable fraction, $c=$ degradation rate, and $t=$ time. The effective degradability (ED) of the dry matter was calculated assuming three passage rates $(2,5$, and $\left.8 \% \mathrm{~h}^{-1}\right)$, by the equation described by Ørskov e Mcdonald (1979): $E D=a+(b \cdot c / c+k)$; where $a=$ soluble fraction, $b=$ potentially degradable fraction in rumen, $c=$ degradation rate, and $k=$ passage rate.

Collected data were tabulated according to the treatments, the assumptions of homoscedasticity and normality tested, and analysis of variance was carried out. The means compared by the Duncan test at 5\% probability using the PROC GLM function, and regression analysis was performed by the PROC REG function of the statistical program SAS (2002).

\section{Results and Discussion}

Total herbage biomass (THB), dead herbage biomass (DHB), and pasture height showed a quadratic response $(\mathrm{P}<0.05)$ to nitrogen fertilization, with maximum values obtained at 303.60, 240.72, and $210.16 \mathrm{~kg} \mathrm{ha}^{-1}$, respectively (Table 1).

Table 1. Total herbage biomass (THB), dead herbage biomass (DHB), nitrogen conversion efficiency (NCE), height $(\mathrm{H})$, and live tiller density (LTD) of deferred Massai grass receiving nitrogen fertilization.

\begin{tabular}{|c|c|c|c|c|c|c|c|}
\hline \multirow{2}{*}{ Parameter } & \multicolumn{5}{|c|}{ Nitrogen $\left(\mathrm{kg} \mathrm{ha}^{-1}\right)$} & \multirow{2}{*}{ Equation } & \multirow{2}{*}{$\mathrm{R}^{2}$} \\
\hline & 0 & 100 & 200 & 300 & 400 & & \\
\hline THB $\left(\mathrm{kg} \mathrm{ha}^{-1}\right)$ & 2.560 .00 & 2.640 .00 & 5.920 .00 & 5.560 .00 & 4.850 .00 & 1 & 0.71 \\
\hline DHB $\left(\mathrm{kg} \mathrm{ha}^{-1}\right)$ & 3.280 .00 & 3.840 .00 & 5.880 .00 & 4.640 .00 & 4.350 .00 & 2 & 0.58 \\
\hline NCE & - & 26.40 & 29.60 & 18.53 & 12.13 & - & - \\
\hline $\mathrm{H}(\mathrm{cm})$ & 65.40 & 142.00 & 143.20 & 130.60 & 87.40 & 3 & 0.91 \\
\hline LTD (number of tillers)* & $78^{\mathrm{c}}$ & $142^{\mathrm{ab}}$ & $177^{\mathrm{a}}$ & $117^{\mathrm{bc}}$ & $101^{\mathrm{bc}}$ & - & - \\
\hline \multicolumn{8}{|c|}{ Correlation } \\
\hline \multirow{2}{*}{ Parameter } & \multicolumn{2}{|c|}{ THB $\left(\mathrm{kg} \mathrm{ha}^{-1}\right)$} & \multicolumn{2}{|c|}{ DHB $\left(\mathrm{kg} \mathrm{ha}^{-1}\right)$} & \multicolumn{3}{|c|}{$\mathrm{H}(\mathrm{cm})$} \\
\hline & $\mathrm{R}$ & $\mathrm{P}$ & $\mathrm{R}$ & $\mathrm{P}$ & $\mathrm{R}$ & \multicolumn{2}{|c|}{$\mathrm{P}$} \\
\hline NCE & 0.57 & 0.0037 & 0.65 & 0.0005 & 0.93 & \multicolumn{2}{|c|}{$<0.0001$} \\
\hline
\end{tabular}

**Number of tillers per area of $0,25 \mathrm{~m} 2$

${ }^{1} \mathrm{Y}=2064.66+22.224 \mathrm{~N}-0.0366 \mathrm{~N}^{2} ;{ }^{2} \mathrm{Y}=3097.00+17.236 \mathrm{~N}-0.0358 \mathrm{~N}^{2} ;{ }^{3} \mathrm{Y}=71.00+0.7566 \mathrm{~N}-0.0018 \mathrm{~N}^{2}$.

As the nitrogen levels were increased, fertilization efficiency decreased, resulting in lower production at nitrogen levels greater than $240.72 \mathrm{~kg} \mathrm{ha}^{-1}$. This reduction might be related to the fact that fertilization efficiency is higher with the application of small doses of fertilizer (LANA, 2007). In addition, pastures subjected to long periods of deferment have lower potential of nitrogen utilization than that in pastures subjected to short deferment periods. This is consistent with the findings of Santos et al. (2009b) that reported a better response in pastures deferred for 73 days than in pastures deferred for 116 days.

A significant linear correlation was observed between nitrogen conversion efficiency (NCE) 
and THB, DHB, and height. Decreased efficiency was reflected as decreased production. Availability of nitrogen in the soil through fertilization is important for forage production, since this nutrient is essential for the production of enzymes that drive the metabolic processes (VITOR et al., 2009). Alexandrino et al. (2010) reported that $\mathrm{N}$ is a constituent of chlorophyll, implying that it directly affects photosynthesis. It can thus be inferred that low nitrogen availability causes a reduction in the plant metabolic rate, owing to reduction in photosynthetic rate, and consequently in productivity. An explanation for the reduction in efficiency of nitrogen fertilization might be that higher lodging in the pastures receiving higher doses of nitrogen, cause greater shading in the basal part, which reduces tillering, and leads to lower production.

There was a positive correlation between THB and DHB, implying that the accumulation of dead herbage increased when total production was high. This result may be explained by the simple fact that the larger production caused by greater nitrogen assimilation increased metabolic rates, which in turn leads to a higher senescence rate. This finding is important for the management of deferred pastures, because increase in nitrogen fertilization without a corresponding increase in the animal stocking rate for consuming the forage, might increase senescence rates, thereby reducing the efficiency of the production system (LOPES et al., 2013).

Based on the regression analysis, it was inferred that the maximum grass height would have been obtained by a nitrogen fertilization level of 210.16 $\mathrm{kg} \mathrm{ha}^{-1}$. However, in the present study, the reduction in NCE contributed to a decrease in plant growth, leading to shorter tillers along with a low THB.

In the study of Santos et al. (2009a), no differences were detected in pasture height owing to greater grass lodging. Height is a parameter of great importance in pasture management, as it is a non-destructive tool for the assessment of forage production (LOPES et al., 2011).

LTD was significantly affected by nitrogen levels (Table 1). The control treatment had the lowest LTD, whereas the highest values were obtained by nitrogen fertilization of 100 and $200 \mathrm{~kg} \mathrm{ha}^{-1}$. The lower density obtained with control treatment was related to reduced plant growth caused by the lack of nitrogen. Already, at the nitrogen levels of 300 and $400 \mathrm{~kg} \mathrm{ha}^{-1}$, the grass was highly lodged, thereby blocking the passage of light, which is necessary for the production of new tillers, as also found by Sbrissia e Silva (2008) in Marandu grass.

The chemical composition of Massai grass showed a significant increase in DM, CP, NDF, $\mathrm{ADF}$, and lignin content in response to nitrogen fertilization (Table 2). For each kilogram of increment in the nitrogen level, DM, CP, NDF, ADF, and lignin content increased by $0.046 \%, 0.0084 \%$, $0.0042 \%, 0.0055 \%$, and $0.0055 \%$, respectively (Table 2).

The increase in dry matter content was associated with increase in fibrous constituents of the cell wall, and reduction of cellular content, owing to the greater proportion of reproductive tillers with longer deference time. Greater presence of the stem fraction owing to secondary thickening with plant maturation increases the concentration of neutral detergent fiber, thereby decreasing the cellular constituents (WILSON, 1993, 1997). The linear increase of the protein content was related to the higher availability of nitrogen in the soil, leading to greater assimilation of this nutrient, and higher concentration in the plant tissue (SANTOS et al., 2010).

The CP content in the nitrogen fertilization treatments of 200,300 , and $400 \mathrm{~kg} \mathrm{ha}^{-1}$ were above the minimum content for herbage to be fermented in the rumen, according to Van Soest (1994). However, recent studies, e.g., Lazzarini et al. (2009), suggest that $\mathrm{CP}$ content below $8 \%$ limit fiber degradation in the rumen due to the reduction of cellulolytic bacteria. 
Table 2. Chemical composition of deferred Massai grass receiving nitrogen fertilization.

\begin{tabular}{cccccccc}
\hline \multirow{2}{*}{ Parameter } & \multicolumn{9}{c}{ Nitrogen $\left(\mathrm{kg} \mathrm{ha}^{-1}\right)$} & \multirow{2}{*}{ Equation } & \multirow{2}{*}{$\mathrm{R}^{2}$} \\
\cline { 2 - 5 } & 0 & 100 & 200 & 300 & 400 & & 0.85 \\
DM & 42.45 & 47.10 & 56.26 & 57.58 & 60.26 & 1 & 0.75 \\
CP & 4.40 & 5.28 & 7.03 & 7.48 & 7.48 & 2 & 0.46 \\
NDF & 71.53 & 73.72 & 72.81 & 73.20 & 73.86 & 3 & 0.56 \\
ADF & 58.59 & 58.98 & 58.28 & 59.38 & 61.23 & 4 & 5 \\
Lignin & 7.70 & 6.96 & 8.99 & 9.28 & 9.30 & 5 & 0.64 \\
\hline
\end{tabular}

$\mathrm{DM}=$ dry matter, $\mathrm{CP}=$ crude protein, $\mathrm{NDF}=$ neutral detergent fiber, $\mathrm{ADF}=$ acid detergent fiber.

*Means not followed by common letters differ significantly (Duncan test at $\mathrm{P}<0.05$ ). Regression analyses at $\mathrm{P}<0.05$.

${ }^{1} \mathrm{Y}=\mathrm{Y}=43.50+0.0460 \mathrm{~N} ;{ }^{2} \mathrm{Y}=\mathrm{Y}=4.660+0.0084 \mathrm{~N} ;{ }^{3} \mathrm{Y}=72.208+0.0042 \mathrm{~N} ;{ }^{4} \mathrm{Y}=58.16+0.0055 \mathrm{~N} ;{ }^{5} \mathrm{Y}=7.344+0.0055 \mathrm{~N}$.

The increase in NDF and ADF contents might be a consequence of the reduction in NCE, and the high flowering rate of the grass, owing likely to the reduction in metabolism of the grass in an attempt to extend its lifetime. This prevented tissue renewal, causing the cell wall content to keep increasing in order to keep the plant alive during the deferment period. Moreover, long deferment periods allow the plant to complete its reproductive cycle and the appearance of inflorescences (SANTOS et al., 2010).

Fertilization with high levels of nitrogen, coupled with favorable conditions, can accelerate plant senescence, thus limiting the beneficial effect of nitrogen fertilization on the cell wall components. Consequently, DM digestibility is reduced, as the percentage of cell wall in DM is inversely correlated with the CP content (VITOR et al., 2009).

The soluble fraction reduced after nitrogen fertilization of $303.60 \mathrm{~kg} \mathrm{ha}^{-1}$ (estimated from the regression equation of THB). This result might be explained by the increased number of reproductive tillers, and the high flowering rate, which resulted in greater NDF and ADF contents.

With increase in nitrogen levels, the potential degradability (PD) of the Massai grass decreased. Control treatment presented a PD of $74.72 \%$, while the treatment with application of $400 \mathrm{~kg}$ nitrogen showed a PD of $68.01 \%$ (Table 3). The rumendegradable fraction was also negatively affected by nitrogen fertilization, with a reduction of $14.43 \%$.

Table 3. Rumen degradation parameters, potential degradation (PD), and effective degradability (ED) of deferred Massai grass receiving nitrogen fertilization.

\begin{tabular}{ccccccccc}
\hline \multicolumn{7}{c}{ Time/Parameter } \\
\hline $\mathrm{N}$ doses of & $a$ & $B$ & $\mathrm{c}$ & $\mathrm{PD}$ & $\mathrm{R}^{2}$ & ED 2\% & ED 5\% & ED 8\% \\
\hline 0 & 11.30 & 66.16 & 2.22 & 74.72 & 95.28 & 47.33 & 34.70 & 29,48 \\
100 & 11.49 & 67.21 & 1.75 & 78.73 & 95.57 & 45.05 & 33.20 & 28,30 \\
200 & 14.72 & 60.72 & 2.00 & 73.00 & 94.03 & 45.73 & 34.04 & 29,56 \\
300 & 15.26 & 59.44 & 2.31 & 68.86 & 94.23 & 45.35 & 34.20 & 29,54 \\
400 & 14.99 & 56.61 & 2.38 & 68.01 & 96.43 & 45.45 & 34.53 & 29,93 \\
\hline
\end{tabular}

soluble fraction, potential degradation, coefficient of determination, and effective degradability for the passage rates of 2,5 , and $8 \% / \mathrm{h}^{-1}$.

The potential degradation $(\mathrm{PD})$ and rumendegradable fraction $(\mathrm{B})$ were reduced due to the increase in plant cell wall fractions (Table 3). NDF, $\mathrm{ADF}$, and lignin content increased with nitrogen fertilization, which directly affected the degradation rate $(c)$ of the grass. In agreement with the findings of Rodrigues et al. (2004), an increase fiber in cell wall content prevents the rumen microorganisms 
from using the energy derived from the forage, because the cell wall stiffening caused by these components creates a barrier that impedes bacterial activity.

\section{Conclusions}

We recommend the use of up to $300 \mathrm{~kg}$ of nitrogen per hectare for the deferred pastures from April to August, given that higher levels of nitrogen reduce forage production, increase fiber content, and decrease dry matter degradability.

\section{Acknowledgements}

This project was financed by FAPEMA and FOPAMA.

\section{References}

ALEXANDRINO, E.; VAZ, R. G. M. V.; SANTOS, A. C. Caracteristícas da Brachiaria Brizantha cv. Marandu durante o seu estabelecimento submetida a diferentes doses de nitrogênio. Bioscience Journal, Uberlândia, v. 26, n. 6, p. 886-893, 2010.

ASSOCIATION OF OFFICIAL ANALYTICAL CHEMISTS - AOAC. Official methods of analysis. $19^{\text {th }}$. Washington: Ed. Gaithersburg: AOAC International, 2012.

BARBOSA, R. A.; ROSA, P. R. da; LIMA, G. de O. Capim-massai manejado em diferentes combinações de intensidade e frequência de corte. In: REUNIÃO ANUAL DA SOCIEDADE BRASILEIRA DE ZOOTECNIA, EMPREENDEDORISMO E PROGRESSO CIENTÍFICOS NA ZOOTECNIA BRASILEIRA DE VANGUARDA, 47., 2010, Salvador. Anais... Salvador: SBZ, 2010. CD-ROM.

CANTARUTTI, R. B.; MARTINS, C. E.; CARVALHO, M. M. de; FONSECA, D. M. de; ARRUDA, M. L.; VILELA, H.; OLIVEIRA, F. T. T. de. Pastagens. In: RIBEIRO, A. C.; GUIMARÃES, P. T. G.; ALVAREZ, V. V. H. Comissão de fertilidade do solo do Estado de Minas Gerais recomendação para o uso de corretivos e fertilizantes em Minas Gerais. $5^{\text {a }}$ Aproximação. Viçosa, MG, p. 332-341, 1999.
EMPRESA BRASILEIRA DE PESQUISA AGROPECUÁRIA - EMBRAPA. Sistema brasileiro de classificação de solos. Brasília: Embrapa, 1999. 412 p.

EUCLIDES, V. P. B.; FLORES, R. S.; MEDEIROS, R. N.; OLIVEIRA, M. P. Diferimento de pastos de braquiária cultivares Basilisk e Marandu, na região do Cerrado. Pesquisa Agropecuária Brasileira, Brasília, v. 42, n. 2, p. 273-280, 2007.

FRANÇA, A. F. S.; BORJAS, A. L. R.; OLIVEIRA, E. R.; SOARES, T. V.; MIYAGI, E. S.; SOUSA, V. R. Parâmetros nutricionais do capim-tanzânia sob doses crescentes de nitrogênio em diferentes idades de corte. Ciência Animal Brasileira, Goiânia, v. 8, n. 4, p. 695703, 2007.

LANA, R. P. Respostas das plantas à fertilização: aspectos biológicos, econômicos e ambientais. In: LANA, R. P. (Ed.). Respostas biológicas aos nutrientes. Viçosa, MG: [s.n], 2007. p. 51-66.

LAZZARINI, I.; DETMAM, E.; SAMPAIO, C. B.; PAULINO, M. F.; VALADARES FILHO, S. C.; SOUZA, M. A.; OLIVEIRA, F. A. Dinâmicas de trânsito e degradação da fibra em detergente neutro em bovinos alimentados com forragem tropical de baixa qualidade e compostos nitrogenados. Arquivo Brasileiro de Medicina Veterinária e Zootecnia, Belo Horizonte, v. 61, n. 3, p. 635-647, 2009.

LOPES, M. N.; CÂNDIDO, M. J. D.; POMPEU, R. C. F. P.; SILVA, R. G.; LOPES, J. W. B.; BEZERRA, F. M. L. Biomass components in Massai grass during establishmentand regrowth under five nitrogen fertilization levels. Revista Brasileira de Zootecnia, Viçosa, MG, v. 40, n. 8, p. 1629-1637, 2011.

LOPES, M. N.; CÂNDIDO, M. J. D.; POMPEU, R. C. F. P.; SILVA, R. G.; LOPES, J. W. B.; FERNANDES, F. R. B.; LACERDA, C. F.; BEZERRA, F. M. L. Fluxo de biomassa em capim-massai durante o estabelecimento e rebrotação com e sem adubação nitrogenada. Revista Ceres, Viçosa, MG, v. 60, n. 3, p. 363-371, 2013.

NOCEK, J. E. In situ and other methods to estimate ruminal protein and energy digestibility: a review. Journal of Dairy Science, Champaign, v. 71, n. 8, p. 2051-2069, 1988.

ØRSKOV, E. R.; McDONALD, I. The estimation of protein degradability in the rumen from incubation measurements weighted according to rate of passage. Journal of Agricultural Science, Cambridge, v. 92, n. 1, p. 499-508, 1979. 
RODRIGUES, A. L. P.; SAMPAIO, I. B. M.; CARNEIRO, J. C.; TOMICH, T. R.; MARTINS, R. G. R. Degradabilidade in situ da matéria seca de forrageiras tropicais obtidas em diferentes épocas de corte. Arquivo Brasileiro de Medicina Veterinária e Zootecnia, Belo Horizonte, v. 56, n. 5, p. 658-664, 2004.

SAMPAIO, I. B. M. Métodos estatísticos aplicados à determinação de digestibilidade in situ. In: TEIXEIRA, J. C. Digestibilidade em ruminantes. Lavras: UFLA, 1995. p. 165-178.

SANTOS, M. E. R.; FONSECA, D. M.; BALBINO, E. M.; MONNERAT, J. P. I. S.; SILVA, S. P. Capimbraquiária diferido e adubado com nitrogênio: produção e características da forragem. Revista Brasileira de Zootecnia, Viçosa, MG, v. 38, n. 4, p. 650-656, 2009 b.

SANTOS, M. E. R.; FONSECA, D. M.; BALBINO, E. M.; SILVA, S. P.; MONNERAT, J. P. I. Valor nutritivo de perfilhos e componentes morfológicos em pastos de capim-braquiária diferidos e adubados com nitrogênio. Revista Brasileira de Zootecnia, Viçosa, MG, v. 39, n. 9, p. 1919-1927, 2010.

SANTOS, M. E. R.; FONSECA, D. M.; EUCLIDES, V. P. B.; NASCIMENTO JÚNIOR, D.; QUEIROZ, A. C.; RIBEIRO JÚNIOR, J. I. Características estruturais e índice de tombamento de Brachiaria decumbens cv. Basilisk em pastagens diferidas. Revista Brasileira de Zootecnia, Viçosa, MG, v. 38, n. 4, p. 626-634, 2009a.

SBRISSIA, A. F.; SILVA, S. C. da. Compensação tamanho/densidade populacional de perfilhos em pastos de capim-marandu. Revista Brasileira de Zootecnia, Viçosa, MG, v. 37, n. 1, p. 35-47, 2008.

STATISTICAL ANALYSIS SYSTEM - SAS. System for Microsoft Windows: release 8.2. Cary: Statistical Analysis System, 2002. CD-ROM.
TOMICH, T. R.; SAMPAIO, I. B. M. A new strategy for the determination of forage degradability with an in situ technique through the use of one fistulated ruminant. The Journal of Agricultural Science, v. 142, n. 5, p. 589-593, 2004.

VAN SOEST, P. J. Use of detergents in the analysis of fibrous feeds. 2. A rapid method for the determination of fiber and lignin. Journal of the Association of Official Agricultural Chemists, v. 46, p. 829-835, 1963.

Nutritional ecology of the ruminant. 2. ed. Ithaca, New York: Cornell University Press, 1994. 476 p.

VAN SOEST, P. J.; ROBERTSON, J. B.; LEWIS, B. A. Symposium: carbohydrate methodology, metabolism, and nutritional implications in dairy cattle. Journal of Dairy Science, Savoy, v. 74, n. 10, p. 3583-3597, 1991.

VITOR, C. M. T.; FONSECA, D. D.; CÓSER, A. C.; MARTINS, C. E.; NASCIMENTO JÚNIOR, D.; RIBEIRO JÚNIOR, J. I. Produção de matéria seca e valor nutritivo de pastagem de capim-elefante sob irrigação e adubação nitrogenada. Revista Brasileira de Zootecnia, Viçosa, MG, v. 38, n. 3, p. 435-442, 2009.

WILSON, J. R. Organization of forage plant tissues. In: JUNG, H. G.; BUXTON, D. R.; HATFIELD, R. $\mathrm{D}$ and RALPH, J. Ed. Forage cell wall structure and digestibility. Madison: American Society of Agronomy, Crop Science Society of America, Soil Science Society of America, 1993. p. 1-32.

Structural and anatomical traits of forage influencing their nutritive value for ruminants. In: SIMPÓSIO INTERNACIONAL SOBRE PRODUÇÃO ANIMAL EM PASTEJO, 1997, Viçosa, MG. Anais... Viçosa, MG: Universidade Federal de Viçosa, 1997. p. 173-208. 